\title{
Analisis Implementasi Penyelenggaraan Promosi Kesehatan Rumah Sakit di Era Jaminan Kesehatan Nasional
}

\author{
Muhammad Rae Febrian, Putri Permatasari, Rahmah Hida Nurrizka, Fathinah \\ Ranggauni Hardy \\ Program Studi Kesehatan Masyarakat Universitas Pembangunan Nasional Veteran Jakarta
}

\begin{abstract}
Abstrak
Latar Belakang: Promosi kesehatan rumah sakit (PKRS) merupakan kewajiban yang sangat penting pada era Jaminan Kesehatan Nasional (JKN) dalam melindungi dan meningkatkan status kesehatan masyarakat. Namun saat ini perkembangan PKRS masih berjalan lambat di Indonesia karena belum terjaga prosesnya. Hal tersebut juga terjadi pada salah satu rumah sakit swasta di Tangerang Selatan, dimana berdasarkan studi pendahuluan secara garis besar masih belum optimal seperti standar di Permenkes No. 44 Tahun 2018 tentang PKRS.

Metode: Penelitian ini merupakan penelitian kualitatif yang bersifat deskriptif dan analitik dengan tujuan untuk meninjau faktor yang dapat mempengaruhi implementasi PKRS. Pengambilan data dilakukan dengan menggunakan wawancara mendalam, observasi dan telaah dokumen pendukung penelitian. Analisis data dilakukan dengan menggunakan konsep triangulasi sumber, metode maupun teori. Informan dalam penelitian ini berjumlah 8 orang, yang terdiri dari petugas struktural, fungsional maupun keluarga pasien.

Hasil: Hasil penelitian menunjukkan bahwa implementasi penyelenggaraan PKRS masih belum optimal pelaksanaannya. Meskipun telah adanya dukungan dan komitmen pelaksana yang baik, namun ada faktor lain yang bisa mempengaruhi implementasi konsep tersebut seperti masih belum lengkapnya sumber daya yang dimiliki, komunikasi yang terjalin antar petugas masih kurang terkait aktivitas PKRS, dan masih adanya hambatan sikap pelaksana terkait konsep ini.

Kesimpulan : Diharapkan pihak rumah sakit agar merealisasikan dukungan dan komitmen menjadi suatu kebutuhan untuk mengimplementasikan PKRS dengan optimal.

Kata Kunci : Promosi Kesehatan, Rumah Sakit, Kebijakan

\section{Analysis of Implementation of Hospital Health Promotion Implementation in the Era of National Health Insurance}

\begin{abstract}
Background: Health promotion hospital (HPH) is an obligation that very important in national health insurance (NHI) era for protecting and improving public health status. But nowadays, HPH development is still low in Indonesia because the process is not maintained. The same thing comes from one of private hospital in South Tangerang, where based on early studied in general, it's still not optimal yet as the standards in ministry of health regulation number 44/2018 about $\mathrm{HPH}$.

Method: This is descriptive and analitical from qualitative study with the aim of reviewing factors that can affect implementation of HPH. Data retrieval is done from indepth interview, observation, and document review that support this research. Data analysis is done with triangulation concept (source, methods, theory). Informants in this research were 8 people, comes from structural officer, functional officer and patient family.

Results: Results from this study is showing that implementation of organizing HPH is still not good. Even there are good supports and commitments, but there are still another factors that could affect it concepts such as lack of resources, lack of communication between stakeholders about HPH, and there is barrier attitudes about this concept.

Conclusion : Expected the hospital have to realization their supports and commitments into their needs for implementing optimal HPH.

Keywords : Health Promotion, Hospital, Policy
\end{abstract}

Alamat Korespondensi :

Muhammad Rae Febrian

Fakultas Ilmu Kesehatan, Universitas Pembangunan

Nasional Veteran Jakarta, Jl. Raya Limo, Depok

Email: raenevland@gmail.com 


\section{PENDAHULUAN}

Rumah sakit menurut WHO (World Health Organization) merupakan bagian integral dari fasilitas pelayanan kesehatan yang memiliki kewajiban untuk menyelenggarakan pelayanan kesehatan paripurna mulai dari kuratif, rehabilitatif, preventif sampai promotif. ${ }^{1-3}$ Upaya promotif seharusnya yang dilakukan rumah sakit sesuai dengan Permenkes No. 44 tahun 2018 meliputi 5 tingkat pencegahan konsep dasar kesehatan masyarakat yaitu promosi kesehatan untuk orang yang sehat, spesific protection, early diagnose and prompt treatment, disability limitation serta recovery dan rehabilitation. ${ }^{4}$

Manfaat diterapkannya PKRS dengan baik antara lain dapat memberikan dan menciptakan dampak yang baik terhadap peningkatan literasi, kepuasan dan status kesehatan pasien, masyarakat sekitar dan staff rumah sakit serta memberikan pelayanan dengan kualitas yang tinggi serta aman. ${ }^{5-7}$ Selain itu, dapat menurunkan angka kejadian pasien yang dirawat kembali di rumah sakit (readmission rate $).{ }^{8} \quad$ Sebaliknya jika belum diimplementasikan, masyarakat akan kehilangan haknya untuk menerima informasi dan edukasi kesehatan yang seimbang dan bertanggungjawab sesuai amanat Undang-Undang No. 36 tahun 2009 tentang Kesehatan. ${ }^{9}$

Perkembangan jaringan PKRS masih berjalan lambat pada negara negara yang sedang berkembang dan juga tentu ide tentang promosi kesehatan masih belum dipandang sebagai bagian reformasi sistem kesehatan di negara tersebut. ${ }^{10}$ Salah satunya dalam pelaksanaan PKRS di Indonesia pada 15 tahun terakhir terhitung sejak 2010, implementasinya kurang berjalan dengan baik karena belum terjaga prosesnya sehingga harapan untuk mendapatkan hasil yang optimal belum terealisasi. ${ }^{9,11}$

Penelitian ini penting dilakukan karena promosi kesehatan rumah sakit harus diterapkan diseluruh rumah sakit Indonesia yang berjumlah 2.861 rumah sakit dan menjadi bagian penilaian akreditasi rumah sakit. ${ }^{4,12-14}$
Selain itu dari hasil studi pendahuluan yang telah dilakukan pada salah satu rumah sakit yang ada di Tangerang Selatan, dinyatakan bahwa implementasi penyelenggaraan PKRS masih belum optimal sesuai Permenkes No. 44 tahun 2018 karena ada beberapa faktor yang mempengaruhinya. Oleh karenanya, tujuan dari penelitian ini adalah untuk menganalisis faktor yang dapat mempengaruhi implementasi PKRS di era JKN pada salah satu rumah sakit swasta tipe $\mathrm{C}$ berakreditasi.

\section{METODE}

Penelitian ini menggunakan jenis penelitian kualitatif yang bersifat deskriptif untuk meninjau dan menganalisis variabel terkait faktor yang dapat mempengaruhi implementasi penyelenggaraan PKRS. Variabel yang diteliti adalah dukungan pelaksana, komitmen pelaksana, sumber daya, komunikasi dan sikap pelaksana. Pengumpulan data dilakukan melalui teknik wawancara mendalam (indepth interview) kepada informan yang telah dipilih. Dalam menentukan informan, peneliti menggunakan metode purposive sampling dimana informan penelitian berjumlah 8 orang yang terdiri dari petugas struktural, fungsional maupun keluarga pasien.

Penelitian dilakukan bulan Mei 2019 pada salah satu fasilitas kesehatan rujukan tingkat lanjutan (FKRTL) yaitu rumah sakit swasta di Tangerang Selatan yang telah bekerja sama dengan BPJS Kesehatan. Analisis data dilakukan melalui teknik triangulasi sumber, metode maupun teori. Triangulasi sumber didapatkan melalui perbandingan informasi yang diberikan oleh beberapa informan. Triangulasi Metode didapatkan melalui perbandingan dari kedua metode pengambilan data yaitu wawancara mendalam, observasi dan telaah dokumen. Kemudian, triangulasi teori yang merupakan perbandingan hasil penelitian dengan ketentuan PKRS yang terdapat di Permenkes No. 44 tahun 2018 tentang penyelenggaraan PKRS 


\section{HASIL}

Pada penelitian ini dilakukan analisis terhadap 5 variabel yang memungkinkan dalam mempengaruhi implementasi PKRS, antara lain:

\section{Dukungan Pelaksana dalam PKRS}

Berdasarkan informasi dari informan kunci, perawat yang memiliki peran seharusnya sebagai edukator kesehatan sudah mendukung konsep promosi kesehatan melalui edukasi yang diberikan untuk mempercepat kesembuhan dan mencegah berulangnya penyakit yang sama ketika ia telah sembuh. Selain itu dukungan juga diberikan oleh tenaga struktural rumah sakit yaitu manajer karena adanya akreditasi yang akan dilaksanakan.

"Mendukung banget sebenernya, karena gini kalau pasien sudah tau penyakitnya dan penanganannya itu akan memudahkan kita untuk melayani dia karena dia paham apa yang terjadi pada dirinya.. dia gak akan terlalu nuntut gitu"- (F, 52 tahun)

\section{Komitmen Pelaksana dalam PKRS}

Selain dukungan, variabel selanjutnya yang diteliti yaitu komitmen dari manajemen yang memiliki tanggungjawab program dan para pelaksana, dimana pada tenaga kesehatan, mereka sudah memiliki komitmen untuk memberikan edukasi kepada pasien karena suatu kewajiban bagi mereka.

"Kalau dikatakan komitmen, ya komitmen.. karena kan kita harus bisa memberikan penjelasan ke pasien... itu bagian dari komitmen itu sendiri..”- (F, 52 tahun)

\section{Sumber Daya dalam PKRS}

Dalam variabel sumber daya, rumah sakit telah memiliki anggaraan tahunan dan insidentil untuk fungsional PKRS. Namun masih belum optimalnya kegiatan PKRS yang dilakukan salah satunya karena masalah kualitas dan kuantitas tenaga kesehatan khususnya perawat dalam mengedukasi pasien seperti belum menyeluruh pelatihan komunikasi yang efektif bagi perawat dan jumlahnya yang kurang banyak menghambat proses edukasi pada pasien dengan optimal

"Masih adanya pelaksana yang belum terpapar konsep secara terstruktur misalnya seperti pelatihan komunikasi efektif.. “- (D, 49 tahun)

Sumber daya manusia yang khusus mengelola PKRS sehingga dapat menguatkan aktivitas PKRS masih belum tersedia. Namun fungsi promosi kesehatannya dilakukan oleh sebuah tim temporary yang terdapat tenaga kesehatan seperti dokter, perawat, apoteker dan lainnya.

"Belum ada sdm khusus terkait promkes.. kalo misalnya ada penyuluhan" - (A, 40 tahun)

Keberadaan sarana dan prasarana masih belum mendukung, karena masih ada kekurangan baik kualitas maupun kuantitasnya.

“.. kalo di rs lain kan biasanya ditampilkan lewat tv, video gitukan. jadi mereka tinggal nonton informasinya dan dapet pengetahuan kan.. di kita sarana dan prasarananya masih terbatas. fasilitasny juga belum memadai.. "- $(F, 52$ tahun)

\section{Komunikasi dalam PKRS}

Meskipun telah ada koordinasi untuk pengadaan media edukasi. Namun proses pertukaran informasi melalui komunikasi seperti rapat masih belum terlihat mengarah kepada penguatan aktivitas PKRS. Hal tersebut dapat diketahui dari frekuensi pertemuan atau rapat yang ada masih belum spesifik terkait PKRS.

"Belum sih kalau membahas penkes secara khusus.." - (F, 52 tahun $)$

Perawat juga merasa belum ada instruksi langsung dari atasan untuk bisa menguatkan perannya dalam memberikan edukasi kepada pasien dan keluarganya.

"ya kita mah disini ngelakuin apa aja karena instruksi ya... tapi kan ga disuruh ya.. jadi ya.. kita ngelakuin seadanya aja.. ya gitu paling kurangnya instruksi dari atasan" - $(G, 26$ tahun $)$ 


\section{Sikap Pelaksana dalam PKRS}

Berdasarkan informasi yang diperoleh, terdapat sikap yang beragam terkait konsep PKRS disini, selain sikap tenaga kesehatan yang positif yaitu ada pandangan bawa tugas promosi kesehatan sepenuhnya bukan kewajiban rumah sakit.

"sebenernya kalau promosi kesehatan bukan tugasnya kita juga ya, kita gak sempet buat ngerjain kaya gitu.. kita disini hanya kuratif.. namun edukasi ke pasien tetap terhadap tindakan apa yang kita lakukan. bukan

promosi kesehatan dirumah sakit ya.. udah enggak main main gitu lagi buat ke pasien.." (C, 35 tahun)

Hal serupa juga terjadi melalui pandangan terhadap tenaga promosi kesehatan khusus maupun unit PKRS khusus.

“..Kan gak harus ada sdm yang kerjanya khusus untuk promkes enggak ada.. kita tim gitu ya. humas itu sebagai koordinator nya.. kalau pas mau ada kegiatannya tim itu yang bergerak.. tim itu kan intinya ada dari perawat, dokter, dari penunjang,... promkes ini kan enggak harus ada (unitnya).. kalau untuk promkesnya itu kita sambil jalan.."-( A, 40 tahun)

\section{PEMBAHASAN}

\section{Dukungan Pelaksana dalam PKRS}

Dukungan yang ada hanya bersifat emosional tanpa instrumental berbentuk landasan hukum seperti dalam Permenkes No. 44 tahun 2018 yang mengharuskan rumah sakit memiliki surat keputusan (SK) terkait PKRS secara khusus sehingga dapat mendorong aktivitas PKRS yang lebih baik. ${ }^{4,15,16}$

Dukungan pelaksana dalam bentuk emosional seperti empati, kepedulian, dan perhatian juga seharusnya menjadi aspek penting dalam terjadinya efektivitas program kesehatan masyarakat khususnya upaya promosi kesehatan kepada masyarakat di rumah sakit yang diperlukan guna memberikan pengaruh yang lebih efektif pada intervensi oleh tenaga kesehatan maupun pihak manajemen yang terkait. ${ }^{15,17}$ Dukungan dari pemangku kepentingan baik level tertinggi maupun terendah dibutuhkan untuk penyelenggaraan PKRS yang optimal. ${ }^{18}$ Hal itu selaras dengan penelitian yang dilakukan oleh McHugh et aldalam Yaghoubi et al., dimana, dukungan yang komprehensif (menyeluruh) dapat menjadi faktor pemungkin dalam implementasi PKRS. ${ }^{19}$

\section{Komitmen Pelaksana dalam PKRS}

Komitmen yang dimiliki masih belum terlihat realisasinya seperti yang terdapat pada Permenkes No. 44 tahun 2018 dalam bentuk mengupayakan pemenuhan standar dan prosedur kerja PKRS meliputi regulasi, asesmen, intervensi dan monitoring serta evaluasi. ${ }^{(4)}$ Maka dari itu, Menurut Gumiandari (2013) dalam Khoerunnisa dkk (2018) bahwa komitmen seorang pimpinan salah satunya dapat berbentuk penyusunan kebijakan yang mendorong adanya pelaksanaan pekerjaan sesuai prosedur dan standar kerja. ${ }^{20,21}$

Komitmen organisasi jangka panjang juga diperlukan untuk meningkatkan pengetahuan serta kemampuan individu, sehingga dapat meningkatkan produktivitas, kualitas kerja dan kepuasan kerja. ${ }^{22,23}$ Menurut Johnson dalam McHugh et al., mengatakan bahwa komitmen organisasi sangat diperlukan dalam pelayanan kesehatan yang melayani masyarakat khususnya dalam menyelenggarakan promosi kesehatan rumah sakit. Selain itu, dengan komitmen pelaksana, sikap mereka akan meningkat positif, meningkatkan pemahaman tentang filosofi PKRS dan praktiknya, serta meningkatkan kolaborasi dalam kemampuan bekerja. $^{24}$

Dalam mencapai komitmen yang dapat ditindaklanjuti dari pemangku kepentingan, pihak rumah sakit sudah seharusnya mempertimbangkan regulasi dari pemerintah yang mewajibkan optimalisasi PKRS salah satunya melalui akreditasi. Selain itu, diharapkan rumah sakit dengan keseriusannya mempelajari hasil penelitian tentang PKRS, mencari bukti pendukung dan penguat program, kemudian hasilnya dibahas bersama untuk mencapai satu kesatuan komitmen seluruh pihak rumah sakit. $4,12,25$ 


\section{Sumber Daya dalam PKRS}

Jika merujuk pada Permenkes No. 44 Tahun 2018 tentang PKRS dan indikator akreditasi, sudah sejatinya rumah sakit mampu memberikan perhatian yang lebih pada sisi sumber daya khususnya sumber daya manusia demi mengikuti regulasi yang telah dibuat sehingga mempermudah penyelenggaraan promosi kesehatan seperti adanya tenaga promotor kesehatan khusus. ${ }^{4}$

Menurut Afshari et al., keberadaan individu pasti menjadi elemen kunci dalam implementasi PKRS. Maka dari itu individu tersebut harus diberikan pelatihan edukasi terkait konsep promosi kesehatan di rumah sakit sehingga dapat menghindari permasalahan seperti kurangnya pengetahuan petugas akan konsep PKRS, belum optimalnya kemampuan petugas kesehatan, rendahnya efikasi dan motivasi diri untuk memberikan edukasi kesehatan pada masyarakat. ${ }^{26}$

Lee et al., juga memberikan beberapa hambatan yang terjadi pada rumah sakit di Taiwan dan Indonesia dalam menyelenggarakan PKRS salah satunya yaitu masalah kurangnya sumber daya. Sumber daya yang dimaksud dapat berbentuk ketersediaan dana, kemampuan personel/ petugas, alokasi waktu, strategi, serta peran penting kebijakan berwawasan kesehatan. $^{18,27}$

\section{Komunikasi dalam PKRS}

Minimnya rapat khusus terkait PKRS belum sesuai dengan Permenkes No. 44 tahun 2018 menyatakan bahwa diperlukan bentuk komunikasi seperti rapat atau pertemuan antar pemangku kepentingan seperti untuk membuat perencanaan dan evaluasi PKRS yang optimal dengan melibatkan multiprofesi sehingga terciptanya beragam strategi PKRS untuk diterapkan seperti pengadaan panduan praktik klinik (PPK) yang meliputi aktivitas PKRS. ${ }^{4,28}$

Promosi kesehatan membutuhkan peran dari multidisiplin yang profesional serta kolaborasi sektor internal rumah sakit.
Kolaborasi yang baik dimulai saat proses penyampaian informasi melalui proses komunikasi yang dilakukan dengan optimal. ${ }^{29}$ Hubungan sektor internal yang lemah seperti frekuensi pertemuan yang kurang dan hanya bersifat insidentil dalam membahas program PKRS dapat membuat terjadinya komunikasi yang kurang baik antar unit. ${ }^{18,27}$ Sebaliknya, Keshavrz menyatakan bahwa adanya penguatan dalam komunikasi internal dan eksternal suatu organisasi dapat menjadi faktor pemungkin dalam implementasi PKRS. ${ }^{19}$ Peran penting pemimpin yaitu dengan mengarahkan suatu kebijakan terkait kolaborasi sektor internal, mengembangkan prosedur dan struktur koperatif yang konkrit. Selain itu rumah sakit dapat mengadopsi sistem pendekatan bottom up yang mendukung interaksi sosial internal. ${ }^{18}$

\section{Sikap Pelaksana dalam PKRS}

Pandangan yang dimiliki oleh informan kurang sesuai jika dibandingkan dengan regulasi yang ada, seperti pada Permenkes No. 44 Tahun 2018 yang menyatakan bahwa setiap rumah sakit wajib menyelenggarakan promosi kesehatan rumah sakit dengan optimal, salah satunya dengan mengadakan unit khusus PKRS yang meliputi SDM khusus promosi kesehatan. ${ }^{4}$

Selaras dengan penelitian Lee et al., dan Afshari et al., yang menyatakan bahwa sikap pelaksana/staff terhadap suatu implementasi kebijakan PKRS menjadi hambatan yang cukup besar. Bentuk sikapnya antara lain sikap berlepas dirinya dari tanggung jawab melakukan promosi kesehatan, tenaga kesehatan yang kurang tertarik dalam edukasi kesehatan kepada masyarakat dan kurangnya partisipasi karena merasa masih belum diuntungkan melalui insentif. ${ }^{18,26}$

\section{KESIMPULAN}

Penyelenggaraan PKRS yang telah diberi dukungan dan komitmen pelaksana ternyata masih belum optimal karena kurangnya sumber daya pendukung, aktivitas komunikasi antar petugas terkait PKRS masih minim, serta sikap pelaksana yang belum sepenuhnya positif terkait PKRS. Oleh karena itu, Rumah Sakit diharapkan dapat mengikuti konsep PKRS seperti pada Permenkes No. 44 tahun 2018 tentang penyelenggaraan PKRS dengan melibatkan seluruh pemangku kepentingan terkait serta meningkatkan kualitas dan kuantitas 
sumber daya seperti tenaga kesehatan dan sarana penunjang sehingga dapat mendukung terselenggaranya PKRS dengan optimal.

\section{DAFTAR PUSTAKA}

1. Pangerapan DT, Palandeng OELI, Rattu AJM. Hubungan Antara Mutu Pelayanan Dengan Kepuasan Pasien di Poliklinik Penyakit Dalam Rumah Sakit Umum GMIM Pancaran Kasih Manado. 2018;2(1):9-18.

2. Basabih M. Perlukah Keselamatan Pasien Menjadi Indikator Kinerja RS BLU? JARSI. 2017;3(2):150-7.

3. Listiyono RA. Studi Deskriptif Tentang Kuaitas Pelayanan di Rumah Sakit Umum Dr.Wahidin Sudiro Husodo Kota Mojokerto Pasca Menjadi Rumah Sakit Tipe B. J Kebijak dan Manaj Publik [Internet]. 2015;1(1):2-7.Available from: http://journal.unair.ac.id/downloadfullpa perskmp1ad01a2a56full.pdf

4. Kementerian Kesehatan. Permenkes No. 44 Tahun 2018 [Internet]. Indonesia; 2018. Available from: http://ejournal.uajy.ac.id/14649/1/JURN AL.pdf

5. Suurorg L, Groene O, Merisalu E, Alop J, Polluste K, Harm T. Health-promoting hospitals in Estonia: what are they doing differently? Health Promot Int. 2007;22(4):327-36.

6. Khowaja AR, Mistry R, Agha A, Karmaliani R. Potential benefits and perceived need for health promoting hospitals in Pakistan: a healthcare stakeholder ${ }^{\text {ees }}$ perspective. J Pak Med Assoc [Internet]. 2010 Apr [cited 2019 Feb 19];60(4):274-9. Available from: http://www.ncbi.nlm.nih.gov/pubmed/20 419969

7. Miseviciene I, Zalnieraitiene K. Health promoting hospitals in lithuania: Health professional support for standards. Health Promot Int. 2013;28(4):512-21

8. Kementerian Kesehatan. Tingkatkan Pelayanan Kesehatan di RS dengan Penguatan Promosi Kesehatan [Internet]. 2016. Available from: http://www.depkes.go.id/article/print/160 80300003/-tingkatkan-pelayanan- kesehatan-dirs-dengan-penguatan- promosi-kesehatan.html

9. Kementerian Kesehatan. Standar Promosi Kesehatan di Rumah Sakit (PKRS); 2010.

10. Sitanshu KS, Gautam R, Subitha L, Professor A, Sekhar Kar S. Health Promoting Hospital: a Noble Concept. Natl J Community Med [Internet]. 2012;3(3):3. Available from: www.njcmindia.org

11. Thaha RM, Royani JN, Darmawansyah. Efektivitas Implementasi Promosi Kesehatan Rumah Sakit (PKRS). Media Kesehat Masy Indones Univ Hasanuddin. 2017;13(3).

12. KARS. Standar akreditasi rumah sakit edisi 1. Standar Akreditasi Rumah Sakit. 2017;1-421.

13. Sari NP, Nindia DY, Purwanti A. Gambaran Pelaksanaan Promosi Kesehatan Rumah Sakit (PKRS) Di Rumah Sakit Umum Daerah (RSUD) Blambangan Banyuwangi. J Ilm Mhs Kesehat Masy. 2018;03(04):1-9.

14. Kementerian Kesehatan. Data Rumah Sakit Online [Internet]. SIRS Online. 2018 [cited 2019 Jul 10]. Available from: http://sirs.yankes.kemkes.go.id/rsonlin e/data_list.php?ctlSearchFor=\&simple SrchFieldsComboOpt=TglReg\&simpl eSrchTypeComboNot=\&simpleSrchT ypeComboOpt $=$ Contains $\& a=$ integrate $\mathrm{d} \& \mathrm{id}=1 \&$ crite ria $=$ and

15. Sarafino EP, Smith TW. Health Psychology:

Biopsychosocial Interactions. 7th ed. USA: WILEY; 2011

16. RSUD Dr. H. Moh. Anwar. Surat Keputusan Direktur RSUD Dr. H. Moh. Anwar Sumenep tentang Panduan Promosi Kesehatan Rumah Sakit. 188//Kep-Dir/435.210/2015 2015.

17. Prehapsari EN. Efektivitas Dinas Kesehatan Kota Surakarta Dalam Program Pemeliharaan Kesehatan Masyarakat Surakarta (Pkms) [Internet]. FiSIP UNS. 2014 [cited 2019 Jun 28]. Available from: 
https://digilib.uns.ac.id/dokumen/detail/3 8181/Efektivitas-Dinas-Kesehatan-KotaSurakarta-Dalam-Program-

Pemeliharaan-Kesehatan-MasyarakatSurakarta-Pkms

18. Lee CB, Chen MS, Wang YW. Barriers to and facilitators of the implementation of health promoting hospitals in Taiwan: A top-down movement in need of ground support. Int J Health Plann Manage. 2014;29(2):197-213.

19. Yaghoubi M, Karamali M, Bahadori M. Effective factors in implementation and development of health promoting hospitals: A systematic review. Health Promot Int. 2018;33(3):1-13.

20. Khoerunnisa FN, Fitriah E, Nurleli. Pengaruh Komitmen Pimpinan dan Partisipasi Anggaran terhadap Kinerja Manajerial. Pros Akunt. 2018;4(1):41826.

21. Fitriani A. Pengaruh Komitmen Pimpinan dan Lingkungan Pengendalian Internal Terhadap Kualitas Laporan Keuangan (Survei Pada SKPD Provinsi Sulawesi Tengah). J Katalogis. 2017;5(4):113-22.

22. Kingkin P, Rosyid HF, Arjanggi R. Kepuasan Kerja dan Masa Kerja Sebagai Prediktor Komitmen Organisasi Pada Karyawan PT Royal Korindah di Purbalingga. J Unissula. 2019;5(1):1732.

23. Nurandini A, Lataruva E. Analisis Pengaruh Komitmen Organisasi Terhadap Kinerja Karyawan (Studi Pada Pegawai Perum PERUMNAS Jakarta). Jur Manaj Fak Ekon dan Bisnis Univ Diponegoro. 2014;11:78-91.
24. McHugh C, Robinson A, Chesters J. Health promoting health services: A review of the evidence. Health Promot Int. 2010;25(2):230-7.

25. Whitehead D. The European Health Promoting Hospitals (HPH) project: how far on? Health Promot Int. 2004;19:25967.

26. Afshari A, Mostafavi F, Latifi A, Ghahnaviyah LA, Pirouzi M, Eslami AA.Hospitals reorientation towards health promotion:A qualitative study of barriers to and strategies for implementation of health promotion in hospitals of Isfahan,Iran.2018;1-11.

27. Gumilang B. Faktor-faktor yang mempengaruhi implementasi kebijakan promosi kesehatan rumah sakit(PKRS) di rumah sakit Universitas Airlangga; 2015.

28. Kesbangpol. Pengertian Rapat Menurut Para Ahli [Internet]. Website. 2016 [cited 2019 Jul 18]. Available from: http://kesbangpol.riau.go.id/media.php?p =detail_artikel\&id=205

29. Kementerian Kesehatan. Promosi Kesehatan Rumah Sakit Lebih Ditekankan [Internet]. 2018 [cited 2019 Apr 2]. Available from: http://www.depkes.go.id/article/print/181 12900003/promosi-kesehatan-rumahsakit-lebih-ditekankan.html 